\title{
Protein trafficking in Plasmodium falciparum-infected red cells and impact of the expansion of exported protein families
}

\author{
SURENDRA K. PRAJAPATI ${ }^{1}$, RICHARD CULLETON ${ }^{2}$ and OM P. SINGH ${ }^{1}$ \\ ${ }^{1}$ Molecular Biology Division, National Institute of Malaria Research, New Delhi, India \\ ${ }^{2}$ Malaria Unit, Institute for Tropical Medicine (NEKKEN), Nagasaki University, Nagasaki, Fapan
}

(Received 8 August 2013; revised 12 May 2014; accepted 12 May 2014; first published online 30 Fuly 2014)

SUMMARY

Erythrocytes are extensively remodelled by the malaria parasite following invasion of the cell. Plasmodium falciparum encodes numerous virulence-associated and host-cell remodelling proteins that are trafficked to the cytoplasm, the cell membrane and the surface of the infected erythrocyte. The export of soluble proteins relies on a sequence directing entry into the secretory pathways in addition to an export signal. The export signal consisting of five amino acids is termed the Plasmodium export element (PEXEL) or the vacuole transport signal (VTS). Genome mining studies have revealed that PEXEL/VTS carrying protein families have expanded dramatically in P. falciparum compared with other malaria parasite species, possibly due to lineage-specific expansion linked to the unique requirements of $P$. falciparum for host-cell remodelling. The functional characterization of such genes and gene families may reveal potential drug targets that could inhibit protein trafficking in infected erythrocytes. This review highlights some of the recent advances and key knowledge gaps in protein trafficking pathways in P. falciparum-infected red cells and speculates on the impact of exported gene families in the trafficking pathway.

Key words: Plasmodium falciparum, erythrocyte remodelling, protein trafficking, exported proteins, gene family expansion.

\section{INTRODUCTION}

Malaria is an infectious vector-borne disease responsible for significant global morbidity and mortality (Snow et al. 2005). The vast majority of the fatal cases of malaria are caused by Plasmodium falciparum, although Plasmodium vivax, which is itself responsible for huge morbidity (Mendis et al. 2001), may also, although rarely, be severe and fatal (Kochar et al. 2005; Rogerson and Carter, 2008; Suwanarusk et al. 2008; ter Kuile and Rogerson, 2008; Tjitra et al. 2008; Andrade et al. 2010). The sequestration of parasitized erythrocytes in the deep vasculature is the main cause of the pathology of severe falciparum malaria. Mature trophozoites and schizonts sequester in the peripheral circulation due to the adhesion of infected erythrocytes to endothelial cells (cytoadherence) and with uninfected erythrocytes (rosetting) leading to significantly impaired blood circulation (Miller et al. 1994). Infected erythrocytes also become more rigid and adhere to different cell types (Raventos-Suarez et al. 1985).

The malaria parasite modifies its host-cell environment, presumably to enhance its own survival, and this leads to pathological consequences for the host. While all stages of the parasite modify their host cell to a certain extent, infected erythrocytes are subject to extensive modifications that are vital for parasite

* Corresponding author: Molecular Biology Division, National Institute of Malaria Research, New Delhi, India. E-mail: surendramrc@gmail.com survival (Miller et al. 1994). Human erythrocytes lack protein trafficking machinery, so, following invasion, $P$. falciparum first has to establish a trafficking pathway to export various proteins to the surface of the infected cell.

HOST-CELL MODIFICATION AND PROTEIN TRAF F I C K ING

The modification of the erythrocyte from a freeflowing and essentially non-adhesive cell to one that is capable of adhering to endothelial cells and noninfected erythrocytes (Miller et al. 1994) highlights the dramatic modification that occurs following the invasion of the malaria parasite. Major changes that occur in the infected erythrocyte include the formation of small protrusions on the surface of the cell (knobs), alterations in ion channel behaviour (Decherf et al. 2004; Staines et al. 2007), the formation of novel channels for nutrient import (Saliba et al. 1998; Desai et al. 2000; Staines et al. 2004), membrane rigidity and cell deformability (Glenister et al. 2002) and altered behaviour of infected erythrocytes in the microcirculation (DiezSilva et al. 2012). These modifications occur as a result of the export of various effector proteins in the infected erythrocyte. Mature erythrocytes are devoid of any endogenous vesicle trafficking machinery; therefore, for the parasite to export proteins, it needs to establish its own trafficking pathway. The major obstruction for protein export in the infected 


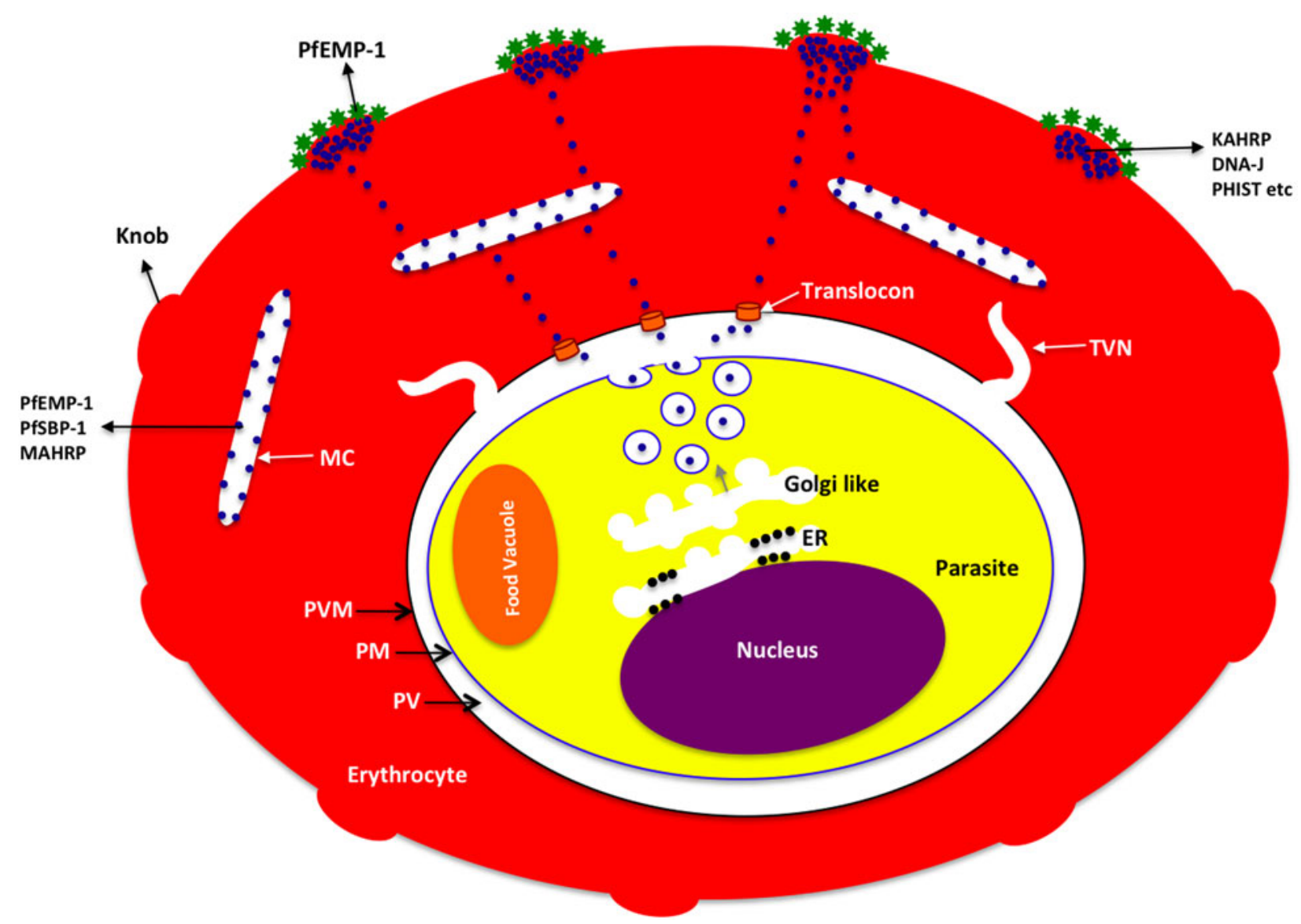

Fig. 1. Diagrammatic representation of channel-mediated soluble protein trafficking in the P. falciparum-infected erythrocyte. The figure shows exported proteins most likely exported via the secretory vesicle pathway. These proteins are recognized and processed (signal sequence and PEXEL) in Golgi-like bodies and then accumulate in small secretory vesicles that extend towards the parasite plasma membrane (PPM). After reaching PPM, a secretory vesicle becomes fused with PPM and discharges its soluble proteins in PV. The exported proteins then translocate the PVM with the help of a translocon present in PVM and enter its destinations in erythrocytes such as red cell cytoplasm, MCs, red cell membrane and the surface of red cells. TVN, tubulo-vesicular network; PV, parasitophorous vacuole; PVM, parasitophorous vacuole membrane; PM, parasite membrane; ER, endoplasmic reticulum; MCs, Maurer's clefts. The modelling channel-mediated trafficking of exported protein in infected erythrocyte is a modified version of Cooke et al. (2004).

erythrocyte is the interface of the parasite and the host-cell cytoplasm, i.e. the parasitophorous vacuole $(\mathrm{PV})$ and its associated membrane (parasitophorous vacuole membrane (PVM)). In order to alter the host cell from a hostile environment to one that is conducive for parasite survival, parasite-encoded proteins have to traverse the PV and the PVM and enter the erythrocyte.

How, then, does the parasite achieve this? To understand protein trafficking beyond the PVM, two pathways of protein export have been proposed: one is vesicle mediated (Gormley et al. 1992; Foley and Tilley, 1998; Taraschi et al. 2001) and the other channel mediated (Gormley et al. 1992; Schatz and Dobberstein, 1996; Foley and Tilley, 1998; Schnell and Hebert, 2003). Plasmodium falciparum proteins thought to be exported via vesicles include PfEMP-1, PfSar1p, Pfsec31p, etc. (Gormley et al. 1992; Ansorge et al. 1996; Trelka et al. 2000; Taraschi et al. 2001, 2003), while soluble proteins such as
KAHRP, PHIST, MESA, PfEMP-3, FIKK kinase, etc. are thought to be exported via the channel pathway (Hiller et al. 2004; Marti et al. 2004; Sargeant et al. 2006). The channel-mediated protein export pathway in P. falciparum is discussed here in detail. First, a signal sequence directs the protein for export to the lumen of the endoplasmic reticulum (ER) where the export signal is recognized and processed for entry into the secretory pathway. Through this secretory pathway, the protein crosses the PV and then the PVM through translocons present in the membrane (de Koning-Ward et al. 2009). The protein then enters the erythrocyte cytosol and is finally directed to its destination, which may be the host-cell cytosol, Maurer's clefts (MCs), the erythrocyte membrane or the surface of the erythrocyte (Fig. 1) (Cooke et al. 2004).

Recently, several key issues in protein export have been elucidated. These include the identification of an export signal (Hiller et al. 2004; Marti et al. 2004), 
the mechanism by which the export signal is processed (Chang et al. 2008; Boddey et al. 2009, 2010; Russo et al. 2010; Bhattacharjee et al. 2012), the physical nature of exported proteins in the PV (Gehde et al. 2009), the translocon machinery (de Koning-Ward et al. 2009) and the role of MCs in directing proteins to the surface of the host cell (Bhattacharjee et al. 2008). Based on these breakthroughs, the channel-mediated protein export pathway has been modelled (Fig. 1) and advances in our current understanding of the various steps involved in protein trafficking are discussed in detail below.

\section{Identification of the export signal and prediction of exported proteins}

A major advance in our understanding of the protein trafficking mechanisms of malaria parasites was the identification of an export signal sequence, and the use of this to predict which proteins the parasite exports (Hiller et al. 2004; Marti et al. 2004). These studies revealed a consensus conserved amino acid motif downstream of the $\mathrm{N}$-terminal sequences of many exported proteins, which was termed the Plasmodium export element (PEXEL) or the vacuole transport signal (V'TS) (Hiller et al. 2004; Marti et al. 2004), which is conserved structurally and functionally across the Plasmodium species infecting humans and birds (Marti et al. 2004). The PEXEL/VTS motif generally lies within a 20-60 amino-acid stretch downstream of the $\mathrm{N}$-terminal sequence of many exported proteins (Hiller et al. 2004; Marti et al. 2004; Sargeant et al. 2006) (Fig. 2). It consists of five amino acids $\mathrm{RxLxE} / \mathrm{Q} / \mathrm{G}$, of which arginine $(\mathrm{R})$ and lysine $(\mathrm{L})$ are essential for recognition whereas the fifth amino acid glutamate $(\mathrm{E})$ is not essential and can be replaced with glutamine (Q) (frequently) or glycine (G) (rarely) (Hiller et al. 2004; Marti et al. 2004) (x could be any amino acid). Further, the PEXEL processed proteins get acetylated at the new N-terminus, which appears to be crucial for recognition and transport of exported proteins to red cells (Chang et al. 2008; Boddey et al. 2009). A recent study has identified that many exported proteins can have a relaxed PEXEL motif (RxLxxE), which is functional and processed by the same mechanism used for canonical PEXEL (Boddey et al. 2013). Based on the updated information of the relaxed PEXEL motif, ExportPred version 1.0 (Sargeant et al. 2006) has been re-designed (version 2.0), which identified 73 additional exported proteins from the falciparum genome (Boddey et al. 2013).

The PEXEL/VTS motif does not appear to be essential for a protein to enter the export pathway, however, as several exported proteins do not possess such a motif. The exported proteins targeted to the host-cell cytoplasm that lack a well-defined

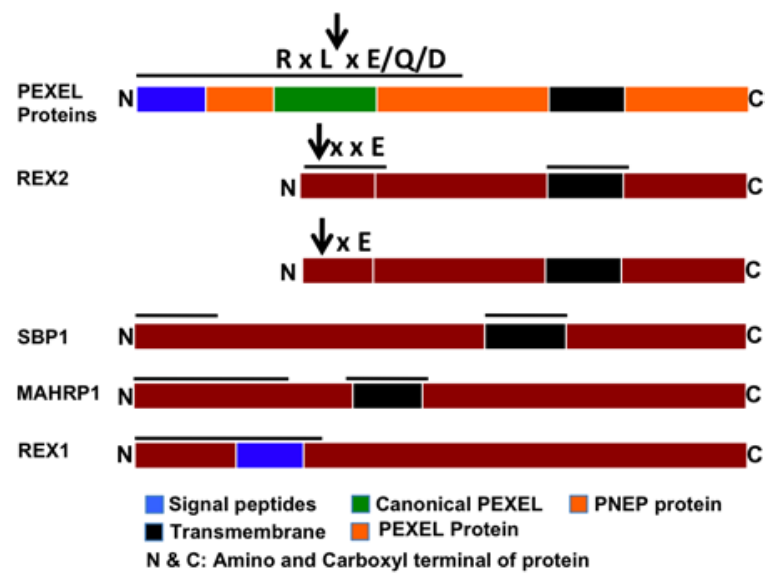

Fig. 2. Diagrammatic representation of P. falciparum PEXEL and PNEP protein structure. The figure represents a typical structure of an exported protein. The arrow indicates ER resident enzyme Plasmepsin- $\mathrm{V}$ that cleaves the PEXEL motif. Scenarios of export of PEXEL-negative exported proteins (PNEPs) are also presented. The bar above the colour indicates hydrophobic regions potentially involved in export and the figure is a modified version of Spielmann and Gilberger (2010).

PEXEL/VTS motif are denoted as PEXEL negative export proteins (PNEPs). These PNEPs include skeleton binding protein-1 (SBP-1), membraneassociated histidine-rich protein-1 (MAHRP-1), and ring export protein-1 and -2 (REX-1 and REX-2) (Blisnick et al. 2000; Spycher et al. 2003; Hawthorne et al. 2004; Spielmann et al. 2006; Haase et al. 2009; Saridaki et al. 2009), which are all resident proteins of MCs. The PNEPs (REX-2, SBP-1 and MAHRP-1) contain a conserved transmembrane domain but lack a signal sequence, whereas REX-1 has a recessed signal sequence (Dixon et al. 2008). These PNEPs have ER intermediates, suggesting export via a classical secretory pathway (Spycher et al. 2006; Dixon et al. 2008; Saridaki et al. 2008; Haase et al. 2009). It is very likely that processing of a signal peptide could also generate a similar $\mathrm{N}$-terminus of PNEPs as generated by Plasmepsin-V; therefore, it has been proposed (Spielmann and Gilberger, 2010) that following processing by a signal peptidase, the trafficking of PNEPs may converge with PEXEL proteins at the translocon. The functional evaluation of Plasmodium export signals in Plasmodium berghei suggests that there may be multiple pathways of protein export for PEXEL and PNEP proteins in non-falciparum malaria parasites (Sijwali and Rosenthal, 2010). Based on the quantity of PEXEL/ VTS positive proteins, it is apparent that the majority of proteins exported by $P$. falciparum are PEXEL/VTS positive, whereas in non-falciparum Plasmodium species, it is the PEXEL/VTSindependent proteins that make up the majority of the exportome ('Table 1). The most well-characterized example of PEXEL/VTS-independent export in 
Table 1. Canonical and non-canonical PEXEL motifs in exported proteins from Plasmodium species

\begin{tabular}{|c|c|c|c|c|c|c|c|c|c|c|}
\hline \multirow[b]{2}{*}{ Plasmodium species } & \multirow[b]{2}{*}{ Gene family } & \multirow[b]{2}{*}{ No. of genes } & \multicolumn{3}{|c|}{ Canonical PEXEL ${ }^{\mathrm{a}}$} & \multicolumn{5}{|c|}{ Non-canonical PEXEL } \\
\hline & & & RxLxE & RxLxD & RxLxQ & $\operatorname{RxLxxE}^{\mathrm{b}}$ & $\mathrm{KxLxE}$ & RxIxE & KxLxD & $\operatorname{RxIxD}$ \\
\hline P. vivax & Vir & 222 & $16(7)$ & $12(4)$ & $6(1)$ & $8(2)$ & $81(21)$ & $13(3)$ & $126(25)$ & $15(1)$ \\
\hline P. cynomolgi & Cyir & 476 & $36(17)$ & $24(7)$ & $6(0)$ & $18(7)$ & $137(56)$ & $34(20)$ & $194(68)$ & $16(7)$ \\
\hline P. knowlesi & SICAVAR & 242 & $25(3)$ & $20(3)$ & $12(1)$ & $19(5)$ & $141(34)$ & $103(7)$ & $107(27)$ & $8(1)$ \\
\hline P. knowlesi & Kir & 60 & $11(1)$ & $6(2)$ & $5(1)$ & $4(0)$ & $25(4)$ & $6(2)$ & $42(8)$ & $7(0)$ \\
\hline P. berghei & Bir & 199 & $7(0)$ & $6(0)$ & $1(0)$ & 0 & $96(39$ & $3(2)$ & $65(5)$ & $2(1)$ \\
\hline P. chabaudi & Cir & 192 & $7(1)$ & $10(4)$ & $1(0)$ & $2(2)$ & $44(6)$ & $6(1)$ & 88 (11) & $3(0)$ \\
\hline P. yoelii & Yir & 785 & $24(2)$ & $14(1)$ & $3(0)$ & $9(0)$ & $237(13)$ & $11(1)$ & $380(16)$ & $16(6)$ \\
\hline P. falciparum & Rifin & 185 & $146(146)$ & $1(1)$ & $2(0)$ & $3(1)$ & $143(6)$ & $3(0)$ & $85(2)$ & $2(0)$ \\
\hline P. falciparum & Stevor & 41 & $13(12)$ & $1(0)$ & $29(29)$ & 0 & $31(15)$ & 0 & $8(5)$ & 0 \\
\hline P. falciparum & RESA like & 71 & $38(38)$ & $12(5)$ & $11(7)$ & $12(2)$ & $29(2)$ & $4(1)$ & $19(1$ & $6(0)$ \\
\hline P. falciparum & PHIST & 67 & $32(31)$ & $12(6)$ & $10(7)$ & $12(3)$ & $29(2)$ & $6(1)$ & $19(1)$ & $4(0)$ \\
\hline P. cynomolgi & $R E S A / R A D$ & 57 & $28(23)$ & $8(5)$ & $6(1)$ & $5(2)$ & $15(1)$ & $4(0)$ & $10(1)$ & $3(1)$ \\
\hline P. falciparum & Surfin & 11 & $1(0)$ & $7(0)$ & $1(0)$ & $2(2)$ & $10(1)$ & $8(1)$ & $11(3)$ & $4(0)$ \\
\hline P. falciparum & Var & 105 & $64(0)$ & $16(0)$ & $15(0)$ & $12(0)$ & $83(10)$ & $31(2)$ & $64(24)$ & $15(1)$ \\
\hline
\end{tabular}

Data obtained from the Plasmodium genome database (www.plasmodb.org). Canonical and non-canonical PEXEL motifs in the most likely exported proteins were estimated using the sequence pattern search tool (http://www-archbac.u-psud.fr/genomics/patternSearch.html). Number indicates number of paralogs in a gene family. Values in parentheses indicate the actual number of gene family members having a defined canonical or non-canonical PEXEL motif.

a Canonical PEXEL cleaved by Plasmepsin-V.

b Non-canonical PEXEL, which is also processed by Plasmepsin-V. 
a non-P. falciparum malaria parasite is the export of the variant surface proteins of $P$. vivax, Plasmodium cynomolgi, Plasmodium knowlesi and Plasmodium yoelii/P. berghei/Plasmodium chabaudi (Table 1). Only a few members of the above variant gene families (Table 1) possess a canonical PEXEL/VTS motif near their signal sequences. Plasmodium vivax VIR proteins provide direct evidence for their export at the surface of infected red blood cells (iRBC; Bernabeu et al. 2012; Lopez et al. 2013). Indirect evidence for export of VIR proteins can be inferred from the structural similarity of VIR subfamilies A and D (Merino et al. 2006) with the exported proteins of $P$. falciparum SURFIN and two transmembrane (Pf2TM) proteins respectively that lack a canonical PEXEL (Sam-Yellowe et al. 2004; Winter et al. 2005; Alexandre et al. 2011). This suggests that the nonfalciparum Plasmodium species may have different mechanisms for the export of proteins necessary for host-cell remodelling and virulence, and corroborates a hypothesis that canonical PEXEL/VTS exported proteins have undergone lineage-specific expansion in the falciparum parasite (Pick et al. 2011). Further, it is unclear whether the greater abundance of canonical PEXEL/VTS proteins in $P$. falciparum is due to the fact that $P$. falciparum requires a high degree of hostcell remodelling compared with non-falciparum malaria parasite species, and so exports more proteins, or to the fact that protein export in the non-falciparum species is mainly mediated through PEXEL/VTSindependent pathways (Pick et al. 2011).

\section{Recognition and processing of the export signal}

Canonical PEXEL/VTS-mediated protein export requires the recognition and processing of the export signal in the ER, the first step of entry of exported proteins into the trafficking/secretory pathway. The canonical PEXEL/VTS motif was initially thought to mediate the trafficking of exported protein across the PV; however, it was later identified as a cleavage site for a parasite protease within the ER (Chang et al. 2008; Boddey et al. 2009). The cleavage of the PEXEL/V'TS motif in exported proteins directs access to the host-cell cytosol (Chang et al. 2008; Boddey et al. 2009). The PEXEL/VTS cleaving protease has been identified as Plasmepsin-V, an aspartic protease localized in the lumen of ER (Klemba and Goldberg, 2005), by two independent studies conducted with $P$. falciparum (Boddey et al. 2010; Russo et al. 2010). Plasmepsin-V recognizes the conserved PEXEL/VTS sequence $(\mathrm{RxLxE} / \mathrm{Q} / \mathrm{D})$ and specifically cleaves between the lysine (L) and glutamate (E) residues (Fig. 2). The cleaved fragment carries an $\mathrm{xE} / \mathrm{Q} / \mathrm{D}$ at the $\mathrm{N}$-terminal of the processed protein that is further $\mathrm{N}$-acetylated (Chang et al. 2008; Boddey et al. 2009) and then recruited into the secretory pathway (Chang et al. 2008).
The conservation of the $\mathrm{xE} / \mathrm{D} / \mathrm{Q}$ residue in a processed protein seems essential for export but not for processing (Boddey et al. 2009). Plasmepsin-V can process canonical PEXEL and relaxed PEXEL as well, such as RxLxxE (Boddey et al. 2013), indicating that this export signal cleaver is capable of processing a larger number of exported proteins $(>400)$. However, genome analysis of Plasmodium species reveals several fixed patterns (relaxed PEXEL) in the $\mathrm{N}$-terminus of various exported proteins (Table 1). Assuming that these non-canonical PEXEL could be processed by a parasite, as these are exported proteins, we can expect that the parasite might have additional ER resident proteases other than the wellknown canonical PEXEL cleaver Plasmepsin-V.

\section{Physical nature of exported proteins in the PV}

Shared physical characteristics of exported proteins that traverse the parasite membrane (PM), PV and PVM may offer clues to aid the elucidation of the export/secretory pathway. It has been shown that exported proteins traverse the $\mathrm{PV}$ in an unfolded form (Gehde et al. 2009) (Fig. 3). The study was performed with a transgenic parasite expressing a chimeric protein in which a functional export signal is fused to green fluorescent protein (GFP) and to murine dihydrofolate reductase (mDHFR). In the presence of WR99210, all chimeric GFP-mDHFR fusion proteins were found to be accumulated in the PV; on the removal of WR99210, successful entry of the chimeric protein was observed in the host-cell cytoplasm. These unfolded proteins must then be refolded in the iRBC and then trafficked to their final destination (Gehde et al. 2009). This study confirms that exported proteins traverse the PV and PVM in an unfolded form and further underlines the putative role of heat shock proteins and molecular chaperones in unfolding exported proteins for successful translocation and refolding in the iRBC. Proteome analysis of $P$. falciparum revealed that the $\mathrm{PV}$ and iRBC are enriched with a number of heat shock proteins (Florens et al. 2002, 2004; Nyalwidhe and Lingelbach, 2006; Acharya et al. 2007). Genome sequence analysis has revealed a large repertoire of exported proteins in $P$. falciparum that are either heat shock proteins (Hiller et al. 2004; Marti et al. 2004; Nyalwidhe and Lingelbach, 2006; Shonhai et al. 2007) or contain the DNA-J domain (which encodes for a molecular chaperone), for example, the seven members of the PHIST-b protein and Hsp40 families (Sargeant et al. 2006; Acharya et al. 2007, 2012), and ring-infected erythrocyte surface antigen (RESA) protein (Favaloro et al. 1986). These proteins emphasize the importance of chaperone molecules in malaria parasite protein export pathways, and offer a relatively unexplored avenue for exportome research. 


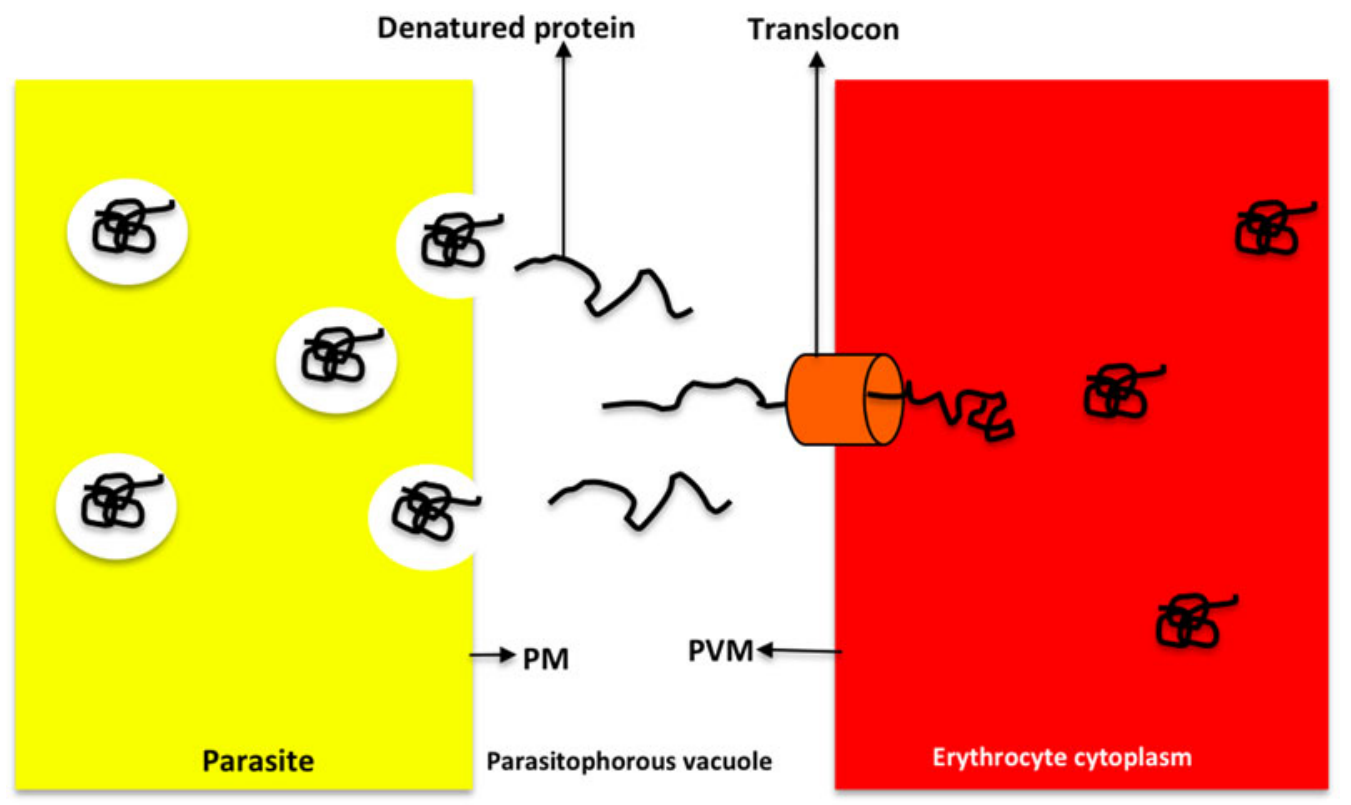

Fig. 3. Schematic representation of an exported protein in the PV in a P. falciparum-infected erythrocyte. Exported proteins enter PV, get unfolded and cross PVM and enter erythrocyte cytoplasm with the help of translocons. In erythrocyte cytoplasm, exported proteins first get refolded with the help of heat shock protein and then reach subcellular locations in erythrocytes. PVM, parasitophorous vacuole membrane; PM, parasite membrane. This image showing translocation of exported protein from PVM is drawn on the basis of work by Gehde et al. (2009).

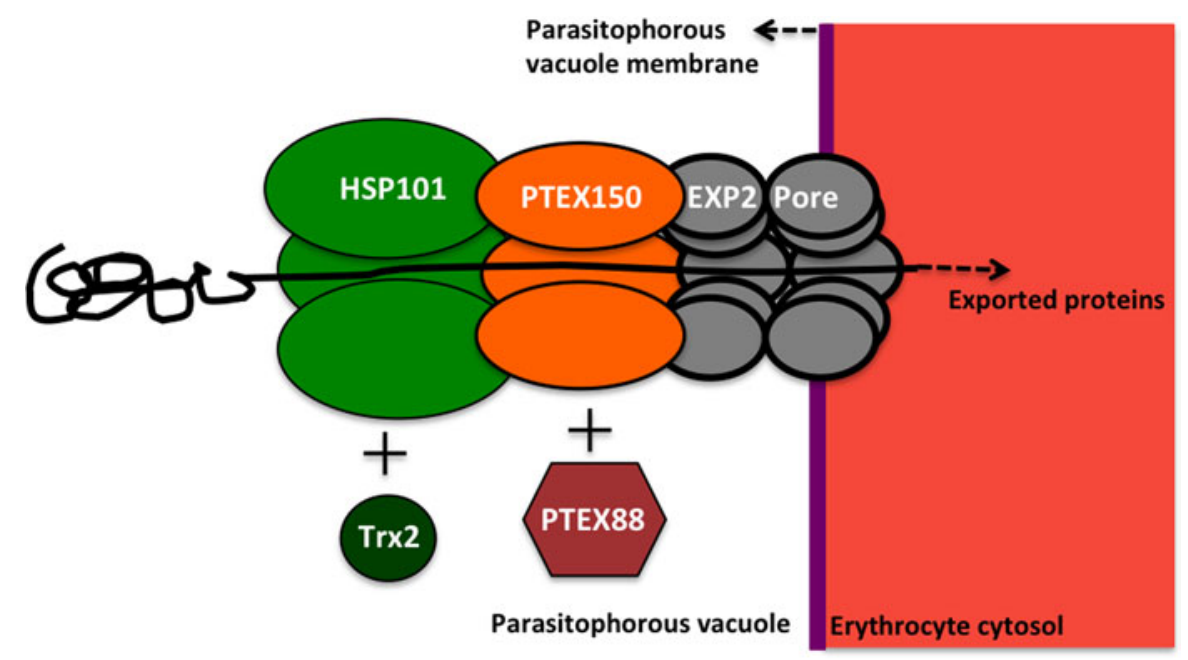

Fig. 4. Molecular composition and structure of the translocon in the PVM of the P. falciparum-infected erythrocyte. PTEX150, Plasmodium translocon of exported protein-150; PTEX88, Plasmodium translocon of exported protein-88; TRX-2, thioredoxin-2; HS101, heat shock protein-101; EXP2, exported protein-2. This figure is a modified version of work by de Koning-Ward et al. (2009) and Bullen et al. (2012).

\section{Identification of translocon machinery in the PVM}

Channel-mediated delivery is a translocon. As channel-mediated protein trafficking necessitates machinery within the PVM to facilitate protein movement through the membrane, so there must exist translocon(s) embedded within the PVM (Schatz and Dobberstein, 1996; Schnell and Hebert, 2003). Such a translocon has recently been described in P. falciparum (de Koning-Ward et al. 2009). It appears that the $P$. falciparum translocon machinery consists of a complex of parasite-encoded proteins embedded within the PVM, termed the Plasmodium translocon of export protein (PTEX). The PTEX complex is an ATP-powered machine and consists of two PTEX proteins (PTEX150 and P'TEX88), a heat shock protein (Hsp101), thioredoxin protein-2 (TRX2) (Matthews et al.2013) and parasite export protein-2 (EXP2) (de Koning-Ward et al. 2009; Bullen et al. 2012; Riglar et al. 2013). A recent study has shown that a homodimer of EXP2 oligomerizes, forms a pore-like shape and attaches to the remainder of the PTEX complex in PVM (Bullen et al. 2012) (Fig. 4). Since P. falciparum exports 
hundreds of highly diverse remodelling and virulence-associated proteins, it is proposed that the parasite may utilize structurally related PVM translocons that may have different accessory proteins or exported proteins may use different cargo. Thus, functional dissection of translocon complexes and modelling of translocon machineries would provide further insights into protein trafficking in P. falciparum.

\section{Trafficking of exported proteins within the erythrocyte cytoplasm}

The fate of exported proteins and the mechanisms behind their journey following their exit from the PVM remains relatively poorly understood. A number of studies have suggested an important role of MCs in the sorting and further trafficking of exported proteins to the surface of infected erythrocytes (Lanzer et al. 2006; Wickert and Krohne, 2007; Bhattacharjee et al. 2008; Tilley et al. 2008). $\mathrm{MCs}$ are parasite-induced, flattened membranous structures scattered throughout the cytoplasm of infected erythrocytes (Spycher et al. 2006). However, it remains to be elucidated how the sorting of proteins to the $\mathrm{RBC}$ membrane and the surface of the iRBC occurs following protein traversal of the PVM. The resident proteins of MCs have been shown to play an important role in the sorting and trafficking of PfEMP-1 from MCs to the erythrocyte surface. These resident proteins include Pf332, PfEMP-3, PfSBP-1 and MAHRP-I (Waterkeyn et al. 2000; Spycher et al. 2003; Maier et al. 2007; Hodder et al. 2009). Previously, it was believed that MCs are responsible for the display of exported proteins on the surface of infected erythrocytes by a mechanism in which MCs ultimately merge with the host-cell membrane (Trelka et al. 2000). Later studies described the role of MCs as a secretory organelle that accumulates parasite proteins and delivers them to the surface of the erythrocyte (Bhattacharjee et al. 2008). Further, a large-scale gene knockout study confirmed their role in the trafficking of PfEMP-1 to the surface of the infected erythrocyte (Maier et al. 2008). The export of PfEMP-1, one of the most wellcharacterized virulence-associated proteins, to the surface of the infected erythrocyte has been proposed to be completed in three phases, early, middle and late, wherein each phase involves a number of other parasite-encoded proteins assisting the trafficking through protein-protein interactions (Maier et al. 2008). Other parasite-encoded proteins involved in PfEMP-1 trafficking to the surface of infected erythrocytes have been reviewed by Sam-Yellowe (2009). Further investigations are required in order to fully understand the mechanisms behind the transport of proteins beyond the PVM to their final destination in the host-cell cytoplasm and on to the RBC surface.

EXPANSION OF GENE FAMILIES INVOLVED IN PROTEIN TRAFFICKING

The number of predicted exported proteins is far fewer in non-falciparum malaria species than in $P$. falciparum when algorithm-based predictions are used (Pick et al. 2011). The majority of predicted exported proteins belong to 27 well-characterized gene families, including stevor, pfemp-1, rifin, fikk kinases, surfin and $p f 2 t m$ and 21 other novel gene families (Sargeant et al. 2006; Boddey et al. 2013). Some of the major novel exported protein-encoding gene families are PHIST, DNA-J and hydrolase proteins (Sargeant et al. 2006). The majority of predicted exported proteins are hypothetical and require further functional characterization and annotation. Furthermore, phylogenetic studies suggest the occurrence of lineage-specific expansion of the phist, DNA-F and FIKK kinases gene families in the P.falciparum genome (Ward et al.2004; Sargeant et al. 2006). One member of the phist-b gene family has been shown to be involved in knob formation (Maier et al. 2008; Acharya et al. 2012).

The expansion of various gene families in $P$. falciparum but not in non-falciparum malaria species suggests that radiation of these gene families may have shaped the specific pathogenesis of this parasite (Sargeant et al. 2006; Pick et al. 2011). The high virulence of $P$. falciparum compared with nonfalciparum malaria species is mainly mediated by the localization of PfEMP-1 on the surface of infected erythrocytes. Studies of the export of PfEMP-1 beyond the PVM have been carried out using the PfEMP-1 protein (Var2CSA) expressed by the CS-2 cloned line of $P$. falciparum that causes placental malaria (Salanti et al. 2004). The genome of this parasite has 59 different PfEMP-1 proteins expressed in a mutually exclusive way so that a single PfEMP-1 protein is expressed during each schizogonic cycle in the blood (Dzikowski et al. 2006a,b). This suggests that the actual number of exported proteins required for the successful expression of PfEMP-1 at the surface of the erythrocyte may be larger than currently thought. A large-scale gene knockout study has described the involvement of various PHIST proteins in PfEMP-1 trafficking as well as in the modification of erythrocyte membrane rigidity (Maier et al. 2008). Recently, a single PHIST protein has been shown to have vital interaction with the ATS domain of PfEMP-1 (Mayer et al. 2012), suggesting a putative role for PHIST proteins in trafficking parasite-encoded proteins in the infected erythrocyte. Therefore, the lineage-specific expansion of PHIST and other export families (Sargeant et al. 2006) may be a specific requirement of 


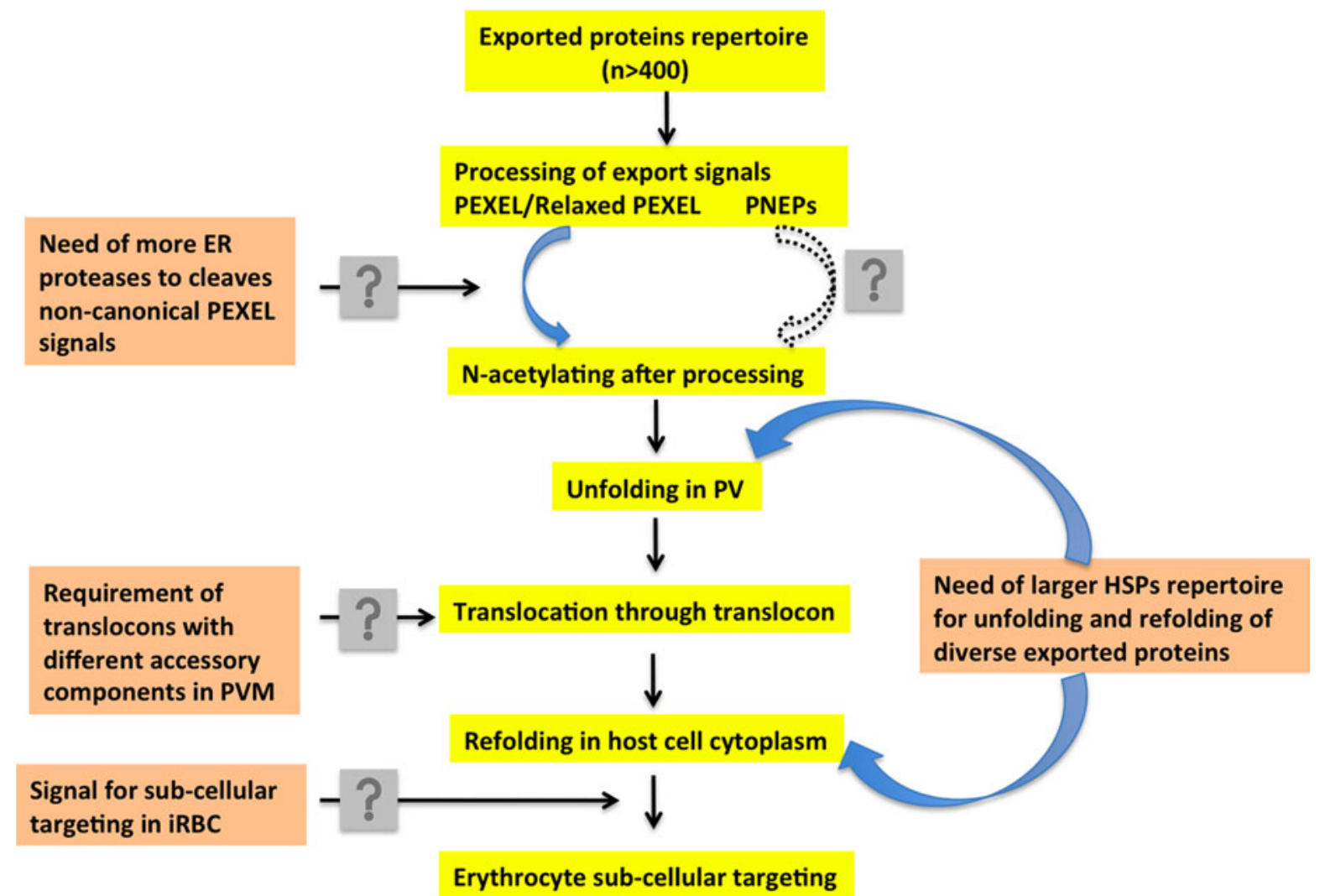

Fig. 5. Diagrammatic representation of the protein export pathway in P. falciparum-infected red cells. The figure shows knowledge gaps in the protein trafficking pathway, which are (1) requirement of additional ER peptidases to process a non-canonical PEXEL signal, (2) requirement of additional translocons that may have structurally related composition as of a well-known translocon, (3) characterization of heat shock proteins that helps unfolding of diverse exported proteins in PV and refolding in infected erythrocyte cytoplasm and (4) characterization of signal in exported proteins for subcellular targeting in infected erythrocytes.

$P$. falciparum relating to the trafficking of host-cell remodelling and virulence-associated proteins.

\section{PERSPECTIVE}

Key advances in analysing protein export beyond the PVM using parasite genetic modification and in vivo imaging technologies have resulted in a clearer understanding of protein trafficking pathways in P. falciparum. Despite these advances, critical parts of the parasite's protein transport mechanisms remain incompletely understood. Based on the current knowledge on protein trafficking in malariainfected erythrocytes and exportome size, a schematic diagram of the protein trafficking pathway (Fig. 5) has been prepared that shows possible knowledge gaps. Many intriguing questions still remain to be answered. For example, does a parasite have multiple ER-resident proteases to process noncanonical PEXEL? Can translocons have different accessory proteins? How do unfolded exported proteins become refolded in the host-cell cytoplasm? How are PEXEL/VT-negative proteins exported beyond the PVM? Is expansion of gene families involved in protein trafficking related to exportome size of a malaria parasite?

The trafficking of parasite-encoded proteins beyond the parasite and into the RBC cytosol and onwards onto the RBC surface is, presumably, unique to malaria parasites. Further characterization of these processes could provide useful knowledge for the design of therapeutics as well as for the elucidation of a fascinating aspect of the biology of the malaria parasite.

\section{ACKNOWLEDGEMENTS}

The authors would like to thank Ms Cherry L. Dykes and Ms Anushrita for editorial corrections. S.K.P. is an ICMRPostdoctoral Fellow.

\section{FINANCIAL SUPPORT}

This work was supported by the Indian Council of Medical Research (ICMR), New Delhi, India.

\section{CONFLICTS OF INTEREST}

The authors declare that there is no conflict of interest. 


\section{REFERENCES}

Acharya, P., Kumar, R. and Tatu, U. (2007). Chaperoning a cellular upheaval in malaria: heat shock proteins in Plasmodium falciparum. Molecular and Biochemical Parasitology 153, 85-94. doi: 10.1016/j.molbio para.2007.01.009.

Acharya, P., Chaubey, S., Grover, M. and Tatu, U. (2012). An exported heat shock protein 40 associates with pathogenesis-related knobs in Plasmodium falciparum infected erythrocytes. PLoS ONE 7, e44605. doi: 10.1371/journal.pone.0044605

Alexandre, J. S., Yahata, K., Kawai, S., Torii, M. and Kaneko, O. (2011). PEXEL-independent trafficking of Plasmodium falciparum SURFIN4.2 to the parasite-infected red blood cell and Maurer's clefts. Parasitology International 60, 313-320. doi: 10.1016/j.parint.2011.05.003.

Andrade, B. B., Reis-Filho, A., Souza-Neto, S. M., Clarencio, J., Camargo, L. M., Barral, A. and Barral-Netto, M. (2010). Severe Plasmodium vivax malaria exhibits marked inflammatory imbalance. Malaria Fournal 9, 13. doi: 10.1186/1475-2875-9-13.

Ansorge, I., Benting, J., Bhakdi, S. and Lingelbach, K. (1996). Protein sorting in Plasmodium falciparum-infected red blood cells permeabilized with the pore-forming protein streptolysin O. Biochemical fournal 315, 307-314

Bernabeu, M., Lopez, F. J., Ferrer, M., Martin-Jaular, L., Razaname, A., Corradin, G., Maier, A. G., Del Portillo, H. A. and Fernandez-Becerra, C. (2012). Functional analysis of Plasmodium vivax VIR proteins reveals different subcellular localizations and cytoadherence to the ICAM-1 endothelial receptor. Cellular Microbiology 14, 386-400. doi: 10.1111/j.1462-5822.2011.01726.x.

Bhattacharjee, S., van Ooij, C., Balu, B., Adams, J. H. and Haldar, K. (2008). Maurer's clefts of Plasmodium falciparum are secretory organelles that concentrate virulence protein reporters for delivery to the host erythrocyte. Blood 111, 2418-2426. doi: 10.1182/blood-2007-09-115279. Bhattacharjee, S., Stahelin, R. V., Speicher, K. D., Speicher, D. W. and Haldar, K. (2012). Endoplasmic reticulum PI(3)P lipid binding targets malaria proteins to the host cell. Cell 148, 201-212. doi: 10.1016/j. cell.2011.10.051

Blisnick, T., Morales Betoulle, M. E., Barale, J. C., Uzureau, P., Berry, L., Desroses, S., Fujioka, H., Mattei, D. and Braun Breton, C. (2000). Pfsbp1, a Maurer's cleft Plasmodium falciparum protein, is associated with the erythrocyte skeleton. Molecular and Biochemical Parasitology 111, 107-121. doi: 10.1016/S0166-6851(00)00301-7.

Boddey, J. A., Moritz, R. L., Simpson, R. J. and Cowman, A. F. (2009). Role of the Plasmodium export element in trafficking parasite proteins to the infected erythrocyte. Traffic 10, 285-299. doi: 10.1111/j.16000854.2008.00864.x.

Boddey, J. A., Hodder, A. N., Gunther, S., Gilson, P. R., Patsiouras, H., Kapp, E. A., Pearce, J. A., de Koning-Ward, T. F., Simpson, R. J., Crabb, B.S. and Cowman, A.F. (2010). An aspartyl protease directs malaria effector proteins to the host cell. Nature 463, 627-631. doi: 10.1038/nature08728.

Boddey, J. A., Carvalho, T. G., Hodder, A. N., Sargeant, T. J., Sleebs, B. E., Marapana, D., Lopaticki, S., Nebl, T. and Cowman, A. F. (2013). Role of plasmepsin V in export of diverse protein families from the Plasmodium falciparum exportome. Traffic 14, 532-550. doi: $10.1111 /$ tra.12053

Bullen, H. E., Charnaud, S. C., Kalanon, M., Riglar, D. T., Dekiwadia, C., Kangwanrangsan, N., Torii, M., Tsuboi, T., Baum, J., Ralph, S. A., Cowman, A.F., de Koning-Ward, T.F., Crabb, B.S. and Gilson, P. R. (2012). Biosynthesis, localization, and macromolecular arrangement of the Plasmodium falciparum translocon of exported proteins (PTEX). Fournal of Biological Chemistry 287, 7871-7884. doi: $10.1074 /$ jbc.M111.328591

Chang, H. H., Falick, A. M., Carlton, P. M., Sedat, J. W., DeRisi, J. L. and Marletta, M. A. (2008). N-terminal processing of proteins exported by malaria parasites. Molecular and Biochemical Parasitology 160, 107-115. doi: 10.1016/j.molbiopara.2008.04.011

Cooke, B. M., Lingelbach, K., Bannister, L. H. and Tilley, L. (2004) Protein trafficking in Plasmodium falciparum-infected red blood cells. Trends in Parasitology 20, 581-589. doi: 10.1016/j.pt.2004.09.008.

Decherf, G., Egee, S., Staines, H. M., Ellory, J. C. and Thomas, S. L. (2004). Anionic channels in malaria-infected human red blood cells. Blood Cells, Molecules and Diseases 32, 366-371. doi: 10.1016/j.bcmd.2004.01.008. de Koning-Ward, T.F., Gilson, P.R., Boddey, J. A., Rug, M., Smith, B. J., Papenfuss, A. T., Sanders, P. R., Lundie, R. J., Maier, A. G., Cowman, A. F. and Crabb, B. S. (2009). A newly discovered protein export machine in malaria parasites. Nature 459, 945-949. doi: 10.1038/nature08104
Desai, S. A., Bezrukov, S. M. and Zimmerberg, J. (2000). A voltagedependent channel involved in nutrient uptake by red blood cells infected with the malaria parasite. Nature 406, 1001-1005. doi: 10.1038/35023000. Diez-Silva, M., Park, Y., Huang, S., Bow, H., Mercereau-Puijalon, O., Deplaine, G., Lavazec, C., Perrot, S., Bonnefoy, S., Feld, M. S., Han, J., Dao, M. and Suresh, S. (2012). Pf155/RESA protein influences the dynamic microcirculatory behavior of ring-stage Plasmodium falciparum infected red blood cells. Scientific Reports 2, 614. doi: 10.1038/srep00614. Dixon, M. W., Hawthorne, P.L., Spielmann, T., Anderson, K. L., Trenholme, K. R. and Gardiner, D. L. (2008). Targeting of the ring exported protein 1 to the Maurer's clefts is mediated by a two-phase process. Traffic 9, 1316-1326. doi: 10.1111/j.1600-0854.2008.00768.x.

Dzikowski, R., Frank, M. and Deitsch, K. (2006a). Mutually exclusive expression of virulence genes by malaria parasites is regulated independently of antigen production. PLoS Pathology 2, e22. doi: 10.1371/journal. ppat.0020022.

Dzikowski, R., Templeton, T. J. and Deitsch, K. (2006b). Variant antigen gene expression in malaria. Cellular Microbiology 8, 1371-1381. doi: 10.1111/j.1462-5822.2006.00760.x.

Favaloro, J. M., Coppel, R. L., Corcoran, L. M., Foote, S. J., Brown, G. V., Anders, R. F. and Kemp, D. J. (1986). Structure of the RESA gene of Plasmodium falciparum. Nucleic Acids Research 14 8265-8277.

Florens, L., Washburn, M.P., Raine, J. D., Anthony, R. M., Grainger, M., Haynes, J. D., Moch, J. K., Muster, N., Sacci, J. B., Tabb, D. L., Witney, A.A., Wolters, D., Wu, Y., Gardner, M. J., Holder, A. A., Sinden, R. E., Yates, J. R. and Carucci, D. J. (2002). A proteomic view of the Plasmodium falciparum life cycle. Nature 419, 520526. doi: 10.1038/nature01107.

Florens, L., Liu, X., Wang, Y., Yang, S., Schwartz, O., Peglar, M., Carucci, D. J., Yates, J. R., III and Wub, Y. (2004). Proteomics approach reveals novel proteins on the surface of malaria-infected erythrocytes. Molecular and Biochemical Parasitology 135, 1-11.

Foley, M. and Tilley, L. (1998). Protein trafficking in malaria-infected erythrocytes. International fournal of Parasitology 28, 1671-1680.

Gehde, N., Hinrichs, C., Montilla, I., Charpian, S., Lingelbach, K. and Przyborski, J. M. (2009). Protein unfolding is an essential requirement for transport across the parasitophorous vacuolar membrane of Plasmodium falciparum. Molecular Microbiology 71, 613-628. doi: 10.1111/j.13652958.2008.06552.x

Glenister, F. K., Coppel, R.L., Cowman, A. F., Mohandas, N. and Cooke, B. M. (2002). Contribution of parasite proteins to altered mechanical properties of malaria-infected red blood cells. Blood 99, 10601063 .

Gormley, J. A., Howard, R. J. and Taraschi, T. F. (1992). Trafficking of malarial proteins to the host cell cytoplasm and erythrocyte surface membrane involves multiple pathways. Fournal of Cell Biology 119, 14811495 .

Haase, S., Herrmann, S., Gruring, C., Heiber, A., Jansen, P. W. Langer, C., Treeck, M., Cabrera, A., Bruns, C., Struck, N.S., Kono, M., Engelberg, K., Ruch, U., Stunnenberg, H. G., Gilberger, T.W. and Spielmann, T. (2009). Sequence requirements for the export of the Plasmodium falciparum Maurer's clefts protein REX2. Molecular Microbiology 71, 1003-1017. doi: 10.1111/j.13652958.2008.06582.x

Hawthorne, P. L., Trenholme, K. R., Skinner-Adams, T.S., Spielmann, T., Fischer, K., Dixon, M.W., Ortega, M. R., Anderson, K. L., Kemp, D. J. and Gardiner, D. L. (2004). A novel Plasmodium falciparum ring stage protein, REX, is located in Maurer's clefts. Molecular and Biochemical Parasitology 136, 181-189.

Hiller, N. L., Bhattacharjee, S., van Ooij, C., Liolios, K., Harrison, T., Lopez-Estrano, C. and Haldar, K. (2004). A host-targeting signal in virulence proteins reveals a secretome in malarial infection. Science $\mathbf{3 0 6}$ 1934-1937. doi: 10.1126/science.1102737.

Hodder, A. N., Maier, A. G., Rug, M., Brown, M., Hommel, M., Pantic, I., Puig-de-Morales-Marinkovic, M., Smith, B., Triglia, T., Beeson, J. and Cowman, A. F. (2009). Analysis of structure and function of the giant protein Pf332 in Plasmodium falciparum. Molecular Microbiology 71, 48-65. doi: 10.1111/j.1365-2958.2008.06508.x.

Klemba, M. and Goldberg, D. E. (2005). Characterization of plasmepsin $\mathrm{V}$, a membrane-bound aspartic protease homolog in the endoplasmic reticulum of Plasmodium falciparum. Molecular and Biochemical Parasitology 143, 183-191. doi: 10.1016/j.molbiopara.2005.05.015.

Kochar, D. K., Saxena, V., Singh, N., Kochar, S. K., Kumar, S. V. and Das, A. (2005). Plasmodium vivax malaria. Emerging Infectious Diseases $\mathbf{1 1}$, 132-134. doi: 10.3201/eid1101.040519.

Lanzer, M., Wickert, H., Krohne, G., Vincensini, L. and Braun Breton, C. (2006). Maurer's clefts: a novel multi-functional organelle in the 
cytoplasm of Plasmodium falciparum-infected erythrocytes. International Fournal of Parasitology 36, 23-36. doi: 10.1016/j.ijpara.2005.10.001.

Lopez, F. J., Bernabeu, M., Fernandez-Becerra, C. and del Portillo, H. A. (2013). A new computational approach redefines the subtelomeric vir superfamily of Plasmodium vivax. BMC Genomics 14, 8 . doi: 10.1186/1471-2164-14-8

Maier, A. G., Rug, M., O’Neill, M.T., Beeson, J. G., Marti, M. Reeder, J. and Cowman, A.F. (2007). Skeleton-binding protein 1 functions at the parasitophorous vacuole membrane to traffic PfEMP1 to the Plasmodium falciparum-infected erythrocyte surface. Blood 109 1289-1297. doi: 10.1182/blood-2006-08-043364

Maier, A. G., Rug, M., O’Neill, M. T., Brown, M., Chakravorty, S., Szestak, T., Chesson, J., Wu, Y., Hughes, K., Coppel, R. L. Newbold, C., Beeson, J. G., Craig, A., Crabb, B.S. and Cowman, A.F. (2008). Exported proteins required for virulence and rigidity of Plasmodium falciparum-infected human erythrocytes. Cell $\mathbf{1 3 4}$ 48-61. doi: 10.1016/j.cell.2008.04.051.

Marti, M., Good, R. T., Rug, M., Knuepfer, E. and Cowman, A. F. (2004). Targeting malaria virulence and remodeling proteins to the hos erythrocyte. Science 306, 1930-1933. doi: 10.1126/science.1102452.

Matthews, K., Kalanon, M., Chisholm, S. A., Sturm, A. Goodman, C. D., Dixon, M. W., Sanders, P. R., Nebl, T., Fraser, F., Haase, S., McFadden, G. I., Gilson, P. R., Crabb, B.S. and de Koning-Ward, T.F. (2013). The Plasmodium translocon of exported proteins (PTEX) component thioredoxin-2 is important for maintaining normal blood-stage growth. Molecular Microbiology 89, 1167-1186. doi: $10.1111 / \mathrm{mmi} .12334$

Mayer, C., Slater, L., Erat, M. C., Konrat, R. and Vakonakis, I. (2012) Structural analysis of the Plasmodium falciparum erythrocyte membrane protein 1 (PfEMP1) intracellular domain reveals a conserved interaction epitope. Fournal of Biological Chemistry 287, 7182-7189. doi: 10.1074/jbc. M111.330779.

Mendis, K., Sina, B. J., Marchesini, P. and Carter, R. (2001). The neglected burden of Plasmodium vivax malaria. American fournal of Tropical Medicine and Hygiene 64(1-2 Suppl.), 97-106.

Merino, E. F., Fernandez-Becerra, C., Durham, A. M., Ferreira, J. E. Tumilasci, V.F., d'Arc-Neves, J., da Silva-Nunes, M. Ferreira, M. U., Wickramarachchi, T., Udagama-Randeniya, P., Handunnetti, S. M. and Del Portillo, H. A. (2006). Multi-character population study of the vir subtelomeric multigene superfamily of Plasmodium vivax, a major human malaria parasite. Molecular and Biochemical Parasitology 149, 10-16. doi: 10.1016/j.molbiopara. 2006.04.002.

Miller, L. H., Good, M. F. and Milon, G. (1994). Malaria pathogenesis. Science 264, 1878-1883.

Nyalwidhe, J. and Lingelbach, K. (2006). Proteases and chaperones are the most abundant proteins in the parasitophorous vacuole of Plasmodium falciparum-infected erythrocytes. Proteomics 6, 1563-1573. doi: 10.1002/ pmic. 200500379.

Pick, C., Ebersberger, I., Spielmann, T., Bruchhaus, I. and Burmester, T. (2011). Phylogenomic analyses of malaria parasites and evolution of their exported proteins. BMC Evolutionary Biology 11, 167 doi: 10.1186/1471-2148-11-167.

Raventos-Suarez, C., Kaul, D. K., Macaluso, F. and Nagel, R. L. (1985). Membrane knobs are required for the microcirculatory obstruction induced by Plasmodium falciparum-infected erythrocytes. Proceedings of the National Academy of Sciences USA 82, 3829-3833.

Riglar, D. T., Rogers, K. L., Hanssen, E., Turnbull, L., Bullen, H. E., Charnaud, S. C., Przyborski, J., Gilson, P. R., Whitchurch, C. B. Crabb, B.S., Baum, J. and Cowman, A. F. (2013). Spatial association with PTEX complexes defines regions for effector export into Plasmodium falciparum-infected erythrocytes. Nature Communications 4, 1415. doi: 10.1038/ncomms 2449 .

Rogerson, S. J. and Carter, R. (2008). Severe vivax malaria: newly recognised or rediscovered. PLoS Medicine 5, e136. doi: 10.1371/journal. pmed.0050136.

Russo, I., Babbitt, S., Muralidharan, V., Butler, T., Oksman, A. and Goldberg, D. E. (2010). Plasmepsin V licenses Plasmodium proteins for export into the host erythrocyte. Nature 463, 632-636. doi: 10.1038/ nature08726.

Salanti, A., Dahlback, M., Turner, L., Nielsen, M. A., Barfod, L., Magistrado, P., Jensen, A. T., Lavstsen, T., Ofori, M. F., Marsh, K., Hviid, L. and Theander, T. G. (2004). Evidence for the involvement of VAR2CSA in pregnancy-associated malaria. Fournal of Experimental Medicine 200, 1197-1203. doi: 10.1084/jem.20041579.

Saliba, K. J., Horner, H. A. and Kirk, K. (1998). Transport and metabolism of the essential vitamin pantothenic acid in human erythrocytes infected with the malaria parasite Plasmodium falciparum. Fournal of Biological Chemistry 273, 10190-10195.

Sam-Yellowe, T.Y. (2009). The role of the Maurer's clefts in protein transport in Plasmodium falciparum. Trends in Parasitology 25, 277-284. doi: 10.1016/j.pt.2009.03.009.

Sam-Yellowe, T.Y., Florens, L., Johnson, J. R., Wang, T., Drazba, J. A., Le Roch, K. G., Zhou, Y., Batalov, S., Carucci, D. J., Winzeler, E. A. and Yates, J. R., III (2004). A Plasmodium gene family encoding Maurer's cleft membrane proteins: structural properties and expression profiling. Genome Research 14, 1052-1059. doi: 10.1101/ gr.2126104.

Sargeant, T.J., Marti, M., Caler, E., Carlton, J. M., Simpson, K., Speed, T.P. and Cowman, A.F. (2006). Lineage-specific expansion of proteins exported to erythrocytes in malaria parasites. Genome Biology 7 , R12. doi: 10.1186/gb-2006-7-2-r12.

Saridaki, T., Sanchez, C.P., Pfahler, J. and Lanzer, M. (2008) A conditional export system provides new insights into protein export in Plasmodium falciparum-infected erythrocytes. Cellular Microbiology $\mathbf{1 0}$, 2483-2495. doi: 10.1111/j.1462-5822.2008.01223.x.

Saridaki, T., Frohlich, K. S., Braun-Breton, C. and Lanzer, M. (2009). Export of PfSBP1 to the Plasmodium falciparum Maurer's clefts. Traffic 10, 137-152. doi: 10.1111/j.1600-0854.2008.00860.x.

Schatz, G. and Dobberstein, B. (1996). Common principles of protein translocation across membranes. Science 271, 1519-1526.

Schnell, D. J. and Hebert, D. N. (2003). Protein translocons: multifunctional mediators of protein translocation across membranes. Cell 112, 491-505. doi: 10.1016/S0092-8674(03)00110-7.

Shonhai, A., Boshoff, A. and Blatch, G. L. (2007). The structural and functional diversity of $\mathrm{Hsp} 70$ proteins from Plasmodium falciparum. Protein Science 16, 1803-1818. doi: 10.1110/ps.072918107.

Sijwali, P.S. and Rosenthal, P.J. (2010). Functional evaluation of Plasmodium export signals in Plasmodium berghei suggests multiple modes of protein export. PLoS ONE 5, e10227. doi: 10.1371/journal. pone.0010227

Snow, R. W., Guerra, C. A., Noor, A. M., Myint, H. Y. and Hay, S. I. (2005). The global distribution of clinical episodes of Plasmodium falciparum malaria. Nature 434, 214-217. doi: 10.1038/nature03342.

Spielmann, T. and Gilberger, T.W. (2010). Protein export in malaria parasites: do multiple export motifs add up to multiple export pathways? Trends in Parasitology 26, 6-10. doi: 10.1016/j.pt.2009.10.001.

Spielmann, T., Hawthorne, P. L., Dixon, M. W., Hannemann, M. Klotz, K., Kemp, D. J., Klonis, N., Tilley, L., Trenholme, K. R. and Gardiner, D. L. (2006). A cluster of ring stage-specific genes linked to a locus implicated in cytoadherence in Plasmodium falciparum codes for PEXEL-negative and PEXEL-positive proteins exported into the host cell. Molecular Biology of the Cell 17, 3613-3624. doi: 10.1091/mbc.E06-040291

Spycher, C., Klonis, N., Spielmann, T., Kump, E., Steiger, S., Tilley, L. and Beck, H.P. (2003). MAHRP-1, a novel Plasmodium falciparum histidine-rich protein, binds ferriprotoporphyrin IX and localizes to the Maurer's clefts. Fournal of Biological Chemistry 278, 35373-35383. doi: 10.1074/jbc.M305851200.

Spycher, C., Rug, M., Klonis, N., Ferguson, D. J., Cowman, A. F., Beck, H. P. and Tilley, L. (2006). Genesis of and trafficking to the Maurer's clefts of Plasmodium falciparum-infected erythrocytes. Molecular and Cellular Biology 26, 4074-4085. doi: 10.1128/MCB.00095-06.

Staines, H. M., Powell, T., Thomas, S. L. and Ellory, J. C. (2004) Plasmodium falciparum-induced channels. International Fournal of Parasitology 34, 665-673. doi: 10.1016/j.ijpara.2004.02.007.

Staines, H. M., Alkhalil, A., Allen, R. J., De Jonge, H. R., Derbyshire, E., Egee, S., Ginsburg, H., Hill, D. A., Huber, S. M., Kirk, K., Lang, F., Lisk, G., Oteng, E., Pillai, A. D., Rayavara, K., Rouhani, S., Saliba, K. J., Shen, C., Solomon, T., Thomas, S. L. Verloo, P. and Desai, S. A. (2007). Electrophysiological studies of malaria parasite-infected erythrocytes: current status. International fournal of Parasitology 37, 475-482. doi: 10.1016/j.ijpara.2006.12.013.

Suwanarusk, R., Chavchich, M., Russell, B., Jaidee, A., Chalfein, F., Barends, M., Prasetyorini, B., Kenangalem, E., Piera, K. A. Lek-Uthai, U., Anstey, N. M., Tjitra, E., Nosten, F., Cheng, Q. and Price, R. N. (2008). Amplification of pvmdr1 associated with multidrugresistant Plasmodium vivax. Fournal of Infectious Diseases 198, 1558-1564. doi: 10.1086/592451

Taraschi, T.F., Trelka, D., Martinez, S., Schneider, T. and O'Donnell, M. E. (2001). Vesicle-mediated trafficking of parasite proteins to the host cell cytosol and erythrocyte surface membrane in Plasmodium falciparum infected erythrocytes. International Fournal of Parasitology 31, 1381-1391. doi: 10.1016/S0020-7519(01)00256-9. 
Taraschi, T.F., O’Donnell, M., Martinez, S., Schneider, T., Trelka, D., Fowler, V. M., Tilley, L. and Moriyama, Y. (2003). Generation of an erythrocyte vesicle transport system by Plasmodium falciparum malaria parasites. Blood 102, 3420-3426. doi: 10.1182/blood2003-05-1448 2003-05-1448.

ter Kuile, F. O. and Rogerson, S. J. (2008). Plasmodium vivax infection during pregnancy: an important problem in need of new solutions. Clinical Infectious Diseases 46, 1382-1384. doi: 10.1086/586744.

Tilley, L., Sougrat, R., Lithgow, T. and Hanssen, E. (2008). The twists and turns of Maurer's cleft trafficking in $P$. falciparum-infected erythrocytes. Traffic 9, 187-197. doi: 10.1111/j.1600-0854.2007.00684.x.

Tjitra, E., Anstey, N. M., Sugiarto, P., Warikar, N., Kenangalem, E., Karyana, M., Lampah, D. A. and Price, R. N. (2008). Multidrugresistant Plasmodium vivax associated with severe and fatal malaria: a prospective study in Papua, Indonesia. PLoS Medicine 5, e128. doi: 10.1371/journal.pmed.0050128.

Trelka, D. P., Schneider, T. G., Reeder, J. C. and Taraschi, T.F. (2000). Evidence for vesicle-mediated trafficking of parasite proteins to the host cell cytosol and erythrocyte surface membrane in Plasmodium falciparum infected erythrocytes. Molecular and Biochemical Parasitology 106, 131-145. doi: 10.1016/S0166-6851(99)00207-8.

Ward, P., Equinet, L., Packer, J. and Doerig, C. (2004). Protein kinases of the human malaria parasite Plasmodium falciparum: the kinome of a divergent eukaryote. BMC Genomics 5, 79. doi: 10.1186/1471-2164-5-79.

Waterkeyn, J. G., Wickham, M.E., Davern, K. M., Cooke, B. M., Coppel, R. L., Reeder, J.C., Culvenor, J.G., Waller, R.F. and Cowman, A.F. (2000). Targeted mutagenesis of Plasmodium falciparum erythrocyte membrane protein 3 (PfEMP3) disrupts cytoadherence of malaria-infected red blood cells. EMBO fournal 19, 2813-2823. doi: 10.1093/emboj/19.12.2813

Wickert, H. and Krohne, G. (2007). The complex morphology of Maurer's clefts: from discovery to three-dimensional reconstructions. Trends in Parasitology 23, 502-509. doi: 10.1016/j.pt.2007.08.008.

Winter, G., Kawai, S., Haeggstrom, M., Kaneko, O., von Euler, A., Kawazu, S., Palm, D., Fernandez, V. and Wahlgren, M. (2005). SURFIN is a polymorphic antigen expressed on Plasmodium falciparum merozoites and infected erythrocytes. Fournal of Experimental Medicine 201, 1853-1863. doi: 10.1084/jem.20041392. 